\title{
Comparison of Emergency and Elective Cesarean Sections in the Breech Presentation: A Case-Control Study
}

\author{
Makat Prezentasyonunda Acil ve Elektif Sezaryenlerin Karşılaştırılması: \\ Vaka Kontrol Çalışması
}

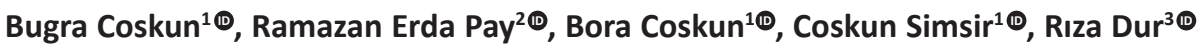 \\ ${\text { Eser } \text { Colak }^{4} \oplus \text {, Kazim Emre Karasahin }}^{2}$ (® \\ ${ }^{1}$ Yüksek ihtisas University, Department of Obstetrics and Gynecology, Ankara, Turkey \\ ${ }^{2}$ Health Science University, Gülhane Training and Research Hospital, Department of Obstetrics and Gynecology, Ankara, Turkey \\ ${ }^{3}$ Health Science University, Etlik Zübeyde Hanım Women Health Training and Research Hospital, Department of Obstetrics and Gynecology, \\ Ankara, Turkey \\ ${ }^{4}$ Başkent University, Konya Application and Research Hospital, Department of Obstetrics and Gynecology, Konya, Turkey
}

Received: 23 November 2019 / Accepted: 25 March 2020 / Publication date: 26 June 2020

Cite as: Coskun B, Pay RE, Coskun B, Simsir C, Dur R, Colak E, Karasahin KE. Comparison of emergency and elective cesarean sections in the breech presentation: a case-control study. Med J Bakirkoy 2020;16(2):132-7.

\begin{abstract}
Objective: In this study, we aimed to compare the characteristics and outcomes between the patients who underwent emergency or elective cesarean section (CS) with the indication of breech presentation (BP).

Method: All the patients who underwent cesarean delivery with the indication of BP between January 2016-December 2018 were included in this retrospective study. BP Patients with any other indication for CS were excluded from the study. Group I; consisting of patients with BP who underwent emergency CS due to progression of cervical dilation and/or effacement, pain or membrane rupture, presence of $\geq 3$ contractions at regular intervals over $25 \mathrm{mmHg}$ within 10 minutes, and Group II; consisting of term pregnant patients without any additional problem who underwent elective CS following 38. gestational weeks between 08:00 AM to 05:00 PM were compared statistically. Also, subgroups were compared according to BP subtypes and cervical opening measurements.

Results: APGAR scores at the 1st / 5 th minutes and postoperative hemoglobin values were significantly lower in the emergency CS group than the elective CS group. Also we found that the decreases in hemoglobin values before and after the cesarean section, and APGAR scores at 1., and 5. min, were significantly higher, the operation time was significantly longer in the emergency CS group. Also, the median value of the week of emergency cesarean section was 37 gestational weeks, and we found that when the cervical dilation was $2 \mathrm{~cm}$ and above before operation, the drop in hemoglobin value, need for blood transfusion and neonatal intensive care increased significantly. No significant difference was found between BP subtypes.

Conclusion: Postoperative parameters may tend to be unfavourable in patients with BP who underwent emergency CS due to pain or progression of cervical dilation. Therefore, clinicians who prefer cesarean delivery in patients with $B P$, should be very cautious against possible emergency operation until the time of the elective operation and also avoid iatrogenic preterm labor.
\end{abstract}

Keywords: emergency cesarean, elective cesarean, breech presentation

Öz

Amaç: Çalışmamızda makat prezentasyonu (MP) endikasyonuyla acil ya da elektif sezaryen (CS) olan hastaların özelliklerini karşılaştırıp, ne gibi klinik yansımaları olduğunu ortaya koymayı amaçlandı.

Yöntem: Şubat 2017-Temmuz 2019 tarihleri arasında hastanemize uterin fibroide yani miyoma bağlı semptomları nedeniyle başvurup UAE tedavi işlemi uygulanan hastaları retrospektif olarak inceledik. Çalışmaya yaşam kalitesini bozacak şekilde miyoma bağlı miktar olarak fazla, uzun süreli, sık ve düzensiz aralıklarla olan uterin kanamalar, anemi, karın ağrısı, ele gelen kitle ve sık idrara çıkma şikayetleri olan hastalar dahil edildi. Tüm hastalarda UAE öncesi ve UAE sonrası 6. ayda, manyetik rezonans görüntüleme (MRG) ile klinik semptomları kaydedildi.

Bulgular: Calıșmamızda acil sezaryan olan MP gebelerde anlamlı olarak 1. ve 5. dakika APGAR skorları ile postoperatif hemoglobin değerinin daha düşük, sezaryen öncesine göre hemoglobin değerindeki düşüşün daha fazla, ve ayrıca operasyon süresinin daha uzun olduğunu buldundu. Ayrıca acil sezaryen ihtiyacı haftasının median değeri 37. hafta olup, CS öncesi servikal dilatasyon $2 \mathrm{~cm}$ ve üstünde olduğunda hemoglobin değerindeki düşüşün arttığını ve ES transfüzyonu ile yenidoğan yoğun bakım ihtiyacının artmakta olduğunu gördük. MP subtipleri arasında fark izlenmedi.

Sonuç: Sancı ya da servikal açılma şüphesi nedeniyle acil sezaryen olan MP gebelerde postoperatif parametreler daha olumsuz yönde olabilmektedir. Bu yüzden MP gebeliklerde elektif CS doğumu tercih eden klinisyenlerin bir yandan elektif operasyon zamanına kadar olası acil bir operasyon hakkında dikkatli olması gerekirken bir yandan da iatrojenik preterm doğumdan kaçınmanın önemli olduğunu düşünmekteyiz.

Anahtar kelimeler: acil sezaryen, elektif sezaryen, makat prezentasyonu

\section{Corresponding Author:}

drbugracoskun@gmail.com
B. Coşkun 0000-0003-1938-3833

R. E. Pay 0000-0001-7183-4246

B. Coşkun 0000-0002-2338-7186

C. Simsir 0000-0003-1825-6584
R. Dur 0000-0002-9225-9030

E. Colak 0000-0002-8184-7531

K. E. Karasahin 0000-0002-4624-4874

(c) Telif hakkı Sağlık Bilimleri Üniversitesi Bakırköy Dr. Sadi Konuk Eğitim ve Araştırma Hastanesi'ne aittir. Logos Tıp Yayıncılık tarafindan yayınlanmaktadır. Bu dergide yayınlanan bütün makaleler Creative Commons Atff-GayriTicari 4.0 Uluslararası Lisansı ile lisanslanmıştr.

(c) Copyright Health Sciences University Bakırköy Sadi Konuk Training and Research Hospital. This journal published by Logos Medical Publishing.

Licenced by Creative Commons Attribution-NonCommercial 4.0 International (CC BY-NC 4.0) 


\section{INTRODUCTION}

The mortality associated with hemorrhage and infection caused mainly by cesarean section (CS) has dramatically declined with the development of infection control measures, blood transfusions, and anesthesia techniques ${ }^{(1)}$. Today, cesarean delivery is considered a safe operation ${ }^{(2)}$ with increasing prevalence around the world ${ }^{(3)}$. It is estimated that around 750,000 CS operations are performed annually in Turkey ${ }^{(4)}$. Although there is no clear consensus on the ideal method of delivery in the breech presentation (BP), which is seen in 3-4\% of all term pregnancies ${ }^{(5)}$, elective $\mathrm{CS}$ is recommended at weeks $39-41$. The prevalence of BP among all CS cases is around $8-12 \%{ }^{(6,7)}$.

Emergency surgeries are associated with greater number of surgical complications than elective surgeries ${ }^{(8)}$. Similarly, emergency CS is likely associated with an increased risk of complications when compared to elective CS. In this study, we aimed to compare the characteristics of BP patients that underwent emergency or elective cesarean delivery and to determine the clinical outcomes.

\section{MATERIAL and METHOD}

This study was granted ethical approval by the relevant Ethics Committee (Health Science University, Gulhane Medical School Local Ethical Committee, Date: 09.25. 2018, Decision Number: 18/230). We retrospectively evaluated data of $\mathrm{BP}$ patients that underwent CS between December 2016 and December 2018. We recorded the demographic characteristics of the patients, the preoperative vaginal examination findings, the pre- and postoperative hemogram parameters, neonatal findings, and adverse clinical events. The patients who underwent CS for any indication other than BP (multiple pregnancies, previous uterine surgery, previous cesarean section, intrauterine development retardation, pregnancy cholestasis, maternal systemic and metabolic diseases, preeclampsia, fetal distress, macrosomia, fetal anomaly, antenatal hemorrhage, etc.) were excluded from the study. None of our subjects tried for vaginal delivery. We considered the suspected start of labor (effacement and/or advanced dilation, three and more contractions of $25 \mathrm{mmHg}$ and higher every 10 minutes at regular intervals observed in cardiotocography) or membrane rupture as an indication of emergency C-section without waiting for active labor. We compared the data of Group I (29 BP patients that underwent an emergency cesarean section) and Group II (patients that underwent elective cesarean section after week 38 without any additional medical conditions).

Elective C-sections were performed during the day within working hours (08:00-16:00) on a predetermined date, where patients had been fasting for an adequate duration of time and had received the required consultations. Emergency CS was not performed on a predetermined date or time but at any time of the day as soon as possible when surgery was indicated by the determined conditions, and under conditions that were available at that time.

Also, subgroups were compared according to BP subtypes and cervical opening measurement subgroups.

\section{Statistical Analysis}

The data were analyzed using SPSS version 23 . We used Kruskal-Wallis and Mann- Whitney U-tests to compare non-normally distributed data. We used the chi-square test to evaluate the distribution of qualitative data according to groups. Qualitative data were expressed as frequency (percent), and quantitative data as mean (minimum-maximum). Level of statistical ignificance was set at $p<0.05$.

\section{RESULTS}

Total number of births was 3216 within the determined time frame. The CS rate was $29.91 \%$, the primary CS rate was $13.08 \%$ and the BP-related CS rate was $4.12 \%$.

There were no statistically significant differences in age, parity, the gender of the baby, birth weight, or median preoperative hemoglobin values of Groups I and II ( $p>0.05)$. The median time of delivery was 37 gestational weeks for Group I and gestational 38.1 weeks for Group II ( $p<0.001)$. The median cervical dilation in the last examination before cesarean delivery was $3 \mathrm{~cm}$ in Group I and $0 \mathrm{~cm}$ in Group II $(p<0.001)$. The median 1- and 5-minute Apgar scores 
of the newborns were similar in both groups; however, the point distributions were significantly different $(\mathrm{pq}<0.05)$. In Group I, the median postoperative hemoglobin value was lower, the postoperative decrease in hemoglobin values was higher, and also the duration of the operation was longer $(p<0.05)$. The median operating time in Groups I and II were 75 and 60 minutes, respectively. There was no statistical difference between the groups in terms of BP subtypes ( $p=0.181)$. The incidence of adverse clinical events [erythrocyte suspension (ES) transfusion, neonatal intensive care, cord prolapse] was significantly higher in Group I. Four patients in Group I and one patient in Group II required ES transfusions. Five infants in Group I and one infant in Group II required neonatal intensive care. Cord prolapse was observed in 2 emergency C-section patients, both of which were in an incomplete breech position (Table 1).

We found that BP subtypes (complete breech, incomplete breech, frank breech) were not associated with parity, gestation time, cervical dilation, gender of the newborn, birth weight, 1- and 5-minute-scores, postoperative hemoglobin values, postoperative decrease in hemoglobin, and operation time (Table 2).
Table 2. Comparison of parameters according to breech position.

\begin{tabular}{lcccc}
\hline & $\begin{array}{c}\text { Frank } \\
\text { Breech* }\end{array}$ & $\begin{array}{c}\text { Complete } \\
\text { Breech* }\end{array}$ & $\begin{array}{c}\text { Incomplete } \\
\text { Breech* }\end{array}$ & p \\
\hline $\begin{array}{l}\text { Apgar } \\
\text { 1-minute }\end{array}$ & $7(4-7)$ & $7(5-7)$ & $7(4-7)$ & 0.722 \\
$\begin{array}{l}\text { Apgar } \\
\text { 5-minute }\end{array}$ & $9(7-9)$ & $9(8-9)$ & $9(6-9)$ & 0.728 \\
$\begin{array}{l}\text { Delta } \\
\text { Hemoglobin } \\
\text { (g/dL) }\end{array}$ & $1(0-4.7)$ & $0.9(0.2-1.5)$ & $1.1(0.1-2.4)$ & 0.382 \\
$\begin{array}{l}\text { Operation } \\
\text { time } \\
\text { (minutes) }\end{array}$ & $60(45-115)$ & $75(50-110)$ & $60(45-90)$ & 0.419 \\
$\begin{array}{l}\text { Emergency } \\
\text { Cesarean } \\
\text { Section }\end{array}$ & $22 / 100(\% 22)$ & $3 / 15(\% 20)$ & $4 / 42(\% 9.5)$ & 0.181 \\
\hline
\end{tabular}

Median (minimum-maximum)

Delta Hemoglobin $=$ [postoperative hemoglobin] - [preoperative hemoglobin]

When patients were grouped according to cervical dilation masurements; In the group where cervical dilation was 0-1 cm, newborn 1 and 5 minute APGAR scores were better, postoperative drop in hemoglobin was lesser and duration of the operation was

Table 1. Comparison of parameters by groups.

\begin{tabular}{|c|c|c|c|}
\hline & $\begin{array}{c}\text { Group I } \\
\text { Emergency Cesarean Section } \\
(\mathrm{n}=29)\end{array}$ & $\begin{array}{c}\text { Group II } \\
\text { Elective Cesarean Section } \\
(\mathrm{n}=124) *\end{array}$ & $\mathrm{p}$ \\
\hline Age* $^{*}$ (years) & $28(22-34)$ & $29(20-36)$ & 0.09 \\
\hline Parity* & $1(1-3)$ & $1(1-4)$ & 0.905 \\
\hline Gestational Week* & 37 (35.1-38.2) & $38.1(37-40)$ & $<0.001$ \\
\hline \multicolumn{4}{|l|}{ Delivery position** } \\
\hline Frank breech & $22(75.9)$ & $78(59.7)$ & 0.181 \\
\hline Complete breech & $3(10.3)$ & $12(9.7)$ & \\
\hline Incomplete breech & $4(13.8)$ & $38(30.6)$ & \\
\hline Dilation $(\mathrm{cm}) *$ & $3(1-8)$ & $0(0-2)$ & $<0.001$ \\
\hline \multicolumn{4}{|l|}{ Gender** } \\
\hline Male & $15(20)$ & $60(80.0)$ & 0.907 \\
\hline Female & $14(17.9)$ & $64(82.1)$ & \\
\hline Weight $(\mathrm{g}) *$ & $2890(1480-3660)$ & 3085 (630-4990) & 0.058 \\
\hline 1-minute Apgar score* & $7(4-7)$ & $7(5-7)$ & $<0.001$ \\
\hline 5-minute Apgar score* & $9(6-9)$ & $9(8-9)$ & $<0.001$ \\
\hline Preoperative Hemoglobin (g/dL) * & $11.8(8.9-14.5)$ & $11.5(9.1-14.4)$ & 0.25 \\
\hline Postoperative Hemoglobin (g/dL) * & $10.1(7.1-13.6)$ & $10.6(7.8-13.3)$ & 0.045 \\
\hline Delta Hemoglobin $(\mathrm{g} / \mathrm{dL}) *$ & $1.7(0.5-4.7)$ & $0.9(0-2.2)$ & $<0.001$ \\
\hline \multicolumn{4}{|l|}{ Adverse clinical events** } \\
\hline None & $18(62.1)$ & $122(98.4)$ & ---- \\
\hline ES transfusion & $4(13.8)$ & $1(0.8)$ & \\
\hline Neonatal intensive care & $5(17.2)$ & $1(0.8)$ & \\
\hline Cord prolapse & $2(6.9)$ & --- & \\
\hline Operation duration (minutes) * & $75(55-115)$ & $60(45-95)$ & $<0.001$ \\
\hline
\end{tabular}

*Median (minimum-maximum)

**Frequency (percentage)

Delta Hemoglobin = [postoperative hemoglobin] - [preoperative hemoglobin] 
Table 3. Comparison of parameters according to cervical dilatation.

\begin{tabular}{|c|c|c|c|c|}
\hline & $\begin{array}{c}\text { Group } 1 \\
(0-1 \mathrm{~cm} \text { cervical dilation) } \\
(\mathrm{n}=119)\end{array}$ & $\begin{array}{c}\text { Group } 2 \\
(2-3 \mathrm{~cm} \text { cervical dilation) } \\
(\mathrm{n}=23)\end{array}$ & $\begin{array}{c}\text { Group } 3 \\
(4 \mathrm{~cm} \text { and more) } \\
(\mathrm{n}=11)\end{array}$ & $\mathbf{p}$ \\
\hline Apgar 1 & $7(5-7)^{a}$ & $7(4-7)^{b}$ & $7(4-7)^{b}$ & $<0.001$ \\
\hline Apgar 5 & $9(8-9)^{a}$ & $9(7-9)^{b}$ & $9(6-9)^{b}$ & $<0.001$ \\
\hline Delta Hemoglobin & $0.9(0-2.5)^{a}$ & $1.4(0.4-3.1)^{b}$ & $1.7(0.5-4.7)^{b}$ & 0.001 \\
\hline Operation time & $60(45-95)^{\text {a }}$ & $75(45-110)^{b}$ & $75(65-115)^{b}$ & $<0.001$ \\
\hline \multicolumn{5}{|c|}{ Adverse clinical events* } \\
\hline No & $117(98.3)$ & 17 (73.9) & $6(54.5)$ & $<0.001$ \\
\hline Yes & $2(1.7)$ & $6(26.1)$ & $5(45.5)$ & \\
\hline \multicolumn{5}{|l|}{ Operation type * } \\
\hline Emergency & $2(1.7)$ & $16(69.6)$ & $11(100)$ & $<0.001$ \\
\hline Elective & $117(98.3)$ & $7(30.4)$ & --- & \\
\hline
\end{tabular}

$a, b:$ The results of the cervical dilation groups marked with the same latter are not statistically different

*frequency (percentage)

Delta Hemoglobin = [postoperative hemoglobin] - [preoperative hemoglobin]

shorter which was statistically different from other groups $(p<0.001)$.

Adverse clinical events (ES transfusion, neonatal intensive care, cord prolapse) were found to be affected by cervical dilation $(p<0.001)$. Cervical dilation was positively correlated with the incidence of adverse clinical events (Table 3).

\section{DISCUSSION}

We found that in the emergency CS group, 1- and 5-minute Apgar scores and postoperative hemoglobin values were lower, the postoperative decrease in hemoglobin values was higher, and also the duration of the operation was longer. The median time of emergency CS was 37. gestational week. We found that a cervical dilation of $2 \mathrm{~cm}$ and more at the operation time was associated with decreased postoperative hemoglobin value, increased need for neonatal intensive care, and ES transfusion. We did not observe any difference between BP subtypes in terms of the parameters mentioned above.

A total of 153 CSs were performed with the indication of BP. As the standard protocol of our clinic vaginal delivery is not performed for $\mathrm{BP}$, so our $\mathrm{CS}$ rate was $100 \%$ for BP patients. The BP rate within all cesarean deliveries was $4.12 \%$. Studies from Turkey indicate the rate of BP among all cases of CS to be $6-12 \%^{(9-11)}$. Our clinic is a referral center, and thus, the rate of complicated pregnancies and the inci- dence of CS are comparatively high. Hence, the rate of $\mathrm{BP}$ within all cases of $\mathrm{CS}$ is comparatively low.

Today, there is still no ideal method of delivery for BP. The first possible option is an external cephalic version (ECV), where delivery is completed vaginally if successful, and surgically, if not. The literature indicates that ECV and its potential complications must be described to the expecting mother in detail, and performed only after their consent (12). Another option is to try vaginal delivery in a breech presentation if ECV fails. Another possible option is a planned CS. The final decision of the delivery method will depend on the experience of the physician, the available facilities and the preference of the expecting mother ${ }^{(13)}$.

ACOG states that vaginal delivery is an option for babies delivered at $\geq 37$. gestational week in an incomplete or complete breech position, that weigh 2500-4000 g, and have not have any fetal abnormalities ${ }^{(13)}$. However, the multicenter randomized 'Term Breech Trial' study published in Lancet in $\mathbf{2 0 0 0}$ found that perinatal and neonatal mortality and severe neonatal morbidity were significantly lower in planned CS when compared to planned vaginal delivery ${ }^{(14)}$. Later studies also evaluated the perspectives of the physician and found that they were more likely to prefer CS for BP ${ }^{(15)}$.

Elective or emergency CS will have different morbidity and mortality outcomes for the mother and the 
baby. There are many studies comparing emergency and elective CS procedures ${ }^{(16-18)}$. The literature defines an elective cesarean section as an operation performed within working hours (typically between 08:00 and 17:00) with an anesthesia team, the neonatal care team and the entire operation team ready at the scheduled time ${ }^{(19)}$. We have based our definition of elective $\mathrm{C}$-section on these criteria. However, there is no consensus both on the delivery method in breech presentation and definitiive criteria for an emergency cesarean section.

Some medical centers prefer to try the external cephalic version in BP and resort to a cesarean section only if it fails, whereas others directly try vaginal birth in BP and switch to emergency cesarean delivery if required due to any indication (non-progressive labor, etc.). Some other medical centers plan CS in BP in the appropriate gestational week and plan an emergency operation in case of pain and dilation, which are considered to indicate a need for CS. Another option is to perform a CS with the start of the first labor contractions and cervical dilation, without planning beforehand. In this case, BP itself has not been considered as an indication for CS until the patient is called a post-term. There are not enough studies on the different forms of management for BP.

However, majorly of physicians prefer cesarean delivery for breech presentations all over the world and in Turkey. Vaginal birth is virtually abondoned due to medicolegal concerns ${ }^{(20)}$. Hence, it becomes harder and harder to find physicians that are experienced in vaginal birth in cases with $B P$.

Physicians tend to plan CS directly without trying vaginal birth in BP. Studies in the literature compare vaginal birth and $C S$ in $B P$, but only include patients that were operated when vaginal birth was tried but failed ${ }^{(21)}$. Our study is the first to compare elective CS with emergency CS that is performed at the onset of the first contraction or cervical dilation (considered as indications for emergency CS) in BP pregnancies.

The median gestation week of the emergency CS patients was 37, whereas it was 38.1 weeks for elective CS patients with BP. This shows that some preg- nant women that are waiting for their scheduled elective CS can undergo emergency CS due to early labor. Preterm and even late preterm births are associated with poor outcomes compared to term births (22). In Turkish medical practice, physicians schedule BP patients a CS before the start of labor. However, false labor pains and cervical dilation that is actually not progressive can lead to an unnecessary preterm birth and bring along the risks associated with emergency CS. If the physician will schedule the CS before the start of labor, they must carefully evaluate cervical dilation and false labor pains to avoid unnecessary preterm birth.

Although there are some studies comparing elective CS and emergency CS performed after complications of vaginal births in the case of BP, our study is the first study to compare elective CS with emergency CS performed due to indication of the onset of contractions and/or cervical dilation in term pregnancies.

The fact that suspicion of the start of the labor is based on subjective evaluation by the physician is the most important limitation of our study. Another significant limitation is not having tried vaginal delivery in $\mathrm{BP}$, and not being able to compare the relevant outcomes.

\section{CONCLUSION}

Postoperative parameters of BP patients can be negatively affected if they undergo emergency CS only because of pain and findings of cervical dilation. We conclude that clinicians should closely follow-up BP patients up until the scheduled elective $\mathrm{CS}$ and be prepared for a possible emergency operation while avoiding iatrogenic preterm birth, if possible.

Ethics Committee Approval: This study was granted ethical approval by the relevant Ethics Committee (Health Science University, Gulhane Medical School Local Ethical Committee, Date: 09.25. 2018, Decision Number: 18/230).

Conflict of Interest: None.

Funding: None.

Informed Consent: None due to the retrospective design of the study. 


\section{REFERENCES}

1. Landon $\mathrm{MB}$, Hauth $\mathrm{JC}$, Leveno $\mathrm{KJ}$, Spong $\mathrm{CY}$, Leindecker $\mathrm{S}$, Varner MW, et al. Maternal and perinatal outcomes associated with a trial of labor after prior cesarean delivery. $\mathrm{N}$ Engl J Med. 2004;351(25):2581-9. https://doi.org/10.1056/NEJMoa040405

2. Notzon FC, Cnattingius S, Bergsj $\varnothing$ P, Cole S, Taffel S, Irgens L, et al. Cesarean section delivery in the 1980's: International comparison by indication. Am J Obstet Gynecol. 1994;170(2):495-504.

https://doi.org/10.1016/S0002-9378(94)70217-9

3. Menacker F, Declercq E, Macdorman MF, editors. Cesarean delivery: background, trends, and epidemiology. Semin Perinatol. 2006;30(5):235-41. https://doi.org/10.1053/j.semperi.2006.07.002

4. Ulubay M, Öztürk M, Fidan U, Keskin U, Fıratlıgil FB, Kıncı MF, et al. Skin incision lengths in caesarean section. Cukurova Medical Journal. 2016;41(1):82-6. https://doi.org/10.17826/cutf.147190

5. Güney G, İnan N, Tokmak A, Doğan M. A different tecnique for head stuck in breech delivery. Gynecology Obstetrics \& Reproductive Medicine. 2015;21(2):109-11. Available from: http://gorm.com.tr/index.php/GORM/article/view/31/26

6. Hofmeyr GJ, Lockwood C, Barss V. Delivery of the fetus in breech presentation. Waltham, MA: UpToDate; 2013.

7. Kolås T, Hofoss D, Daltveit AK, Nilsen ST, Henriksen T, Häger R, et al. Indications for cesarean deliveries in Norway. Am J Obstet Gynecol. 2003;188(4):864-70. https://doi.org/10.1067/mob.2003.217

8. Elveđi-Gašparović V, Klepac-Pulanić T, Peter B. Maternal and fetal outcome in elective versus emergency caesarean section in a developing country. Coll Antropol. 2006;30(1):113-8. PMID: 16617584

9. Yıldız A, Köksal A, Çukurova K, Keklik A, Çelik N, ívit H. Bir obstetrik kliniğinde 15 yıllık period süresince sezaryen oranları ve endikasyonlarının yıllara göre dağılımı. Evaluation. 2010;39:44.

10. Tekirdağ Ai, Cebeci R. Eğitim hastanesinde sezaryen oranları. İstanbul Kanuni Sultan Süleyman Tıp Dergisi (IKSST). 2010;2(1):21-6.

11. Aksoy H, Özyurt S, Aksoy Ü, Açmaz G, Karadağ Öi, Babayiğit MA. Hastanemizdeki sezaryen hızı ve endikasyon dağııımları ışı̆̆ında Türkiye'de sezaryen ile doğuma genel bakış. Kocaeli Tip Dergisi. 2014;3(3):1-7.

12. Hofmeyr GJ, Kulier R, West HM. External cephalic version for breech presentation at term. Cochrane Database Syst Rev. 2015;2015(4):CD000083. https://doi.org/10.1002/14651858.CD000083.pub3
13. ACOG Committee on Obstetric Practice. ACOG Committee Opinion No. 745: Mode of term singleton breech delivery. Obstet Gynecol. 2018;132(2):e60-e63. https://doi.org/10.1097/AOG.0000000000002755

14. Hannah ME, Hannah WJ, Hewson SA, Hodnett ED, Saigal S, Willan AR, et al. Planned caesarean section versus planned vaginal birth for breech presentation at term: a randomised multicentre trial. Lancet. 2000;356(9239):1375-83. https://doi.org/10.1016/S0140-6736(00)02840-3

15. Rietberg CCT, Elferink-Stinkens PM, Visser GH. The effect of the Term Breech Trial on medical intervention behaviour and neonatal outcome in The Netherlands: an analysis of 35,453 term breech infants. BJOG. 2005;112(2):205-9. https://doi.org/10.1111/j.1471-0528.2004.00317.x

16. Suwal A, Shrivastava VR, Giri A. Maternal and fetal outcome in elective versus emergency cesarean section. JNMA J Nepal Med Assoc. 2013;52(192):563-6. PMID: 25327227. https://doi.org/10.31729/jnma.2426

17. Benzouina $S$, Boubkraoui ME-m, Mrabet M, Chahid N, Kharbach A, Elhassani A, et al. Fetal outcome in emergency versus elective cesarean sections at Souissi Maternity Hospital, Rabat, Morocco. Pan Afr Med J. 2016;23:197. https://doi.org/10.11604/pamj.2016.23.197.7401

18. Raees M, Yasmeen S, Jabeen S, Utman N, Karim R. Maternal morbidity associated with emergency versus elective caesarean section. Journal of Postgraduate Medical Institute. 2012;27(1):55-62. Available from: https://www.researchgate. net/publication/282744910

19. Daniel S, Viswanathan M, Simi B, Nazeema A. Comparison of fetal outcomes of emergency and elective caesarean sections in a teaching hospital in Kerala. Academic Medical Journal of India. 2014;2(1):32-6. Available from: https://api.semanticscholar.org/CorpusID:44182723

20. Karabel MP, Demirbaş M, İnci MB. Türkiye'de ve Dünya'da değişen sezaryen sıklığı ve olası nedenleri. Sakarya Med J. 2017;7(4):158-63. Available from: https://dergipark.org.tr/tr/ download/article-file/398631 https://doi.org/10.31832/smj.368600

21. Roman J, Bakos O, Cnattingius S. Pregnancy outcomes by mode of delivery among term breech births: Swedish experience 1987-1993. Obstet Gynecol. 1998;92(6):945-50. https://doi.org/10.1016/S0029-7844(98)00326-3

22. De Luca R, Boulvain M, Irion O, Berner M, Pfister RE. Incidence of early neonatal mortality and morbidity after late-preterm and term cesarean delivery. Pediatrics. 2009;123(6):e106471.

https://doi.org/10.1542/peds.2008-2407 